\title{
Sperm mitochondrial DNA copy numbers in normal and abnormal semen analysis: a systematic review and meta-analysis.
}

\author{
Daria Popova $^{1}$, Priya Bhide ${ }^{1}$, Francesco DAntonio ${ }^{2}$, Purusotam Basnet ${ }^{1}$, and Ganesh \\ Acharya ${ }^{1}$ \\ ${ }^{1}$ UiT The Arctic University of Norway Faculty of Health Sciences \\ ${ }^{2}$ University of Chieti
}

April 11, 2021

\begin{abstract}
Background: Normal mature sperm have a considerably reduced number of mitochondria which provide the energy required for progressive sperm motility. Literature suggests that disorders of sperm motility may be linked to abnormal sperm mitochondrial number and function. Objectives: To summarise the evidence from literature regarding the association of mitochondrial DNA copy numbers and semen quality with a particular emphasis on the spermatozoa motility. Search strategy: Standard methodology recommended by Cochrane. Selection criteria: All published primary research reporting on differences in mitochondrial DNA copy numbers between the sperm of males with a normal and abnormal semen analysis. Data collection and analysis: Using standard methodology recommended by Cochrane we pooled results using a random effects model and the findings were reported as a standardised mean difference. Main results: We included 10 trials. The primary outcome was sperm mitochondrial DNA copy numbers. A meta-analysis including five studies showed significantly higher mitochondrial DNA copy numbers in abnormal semen analysis as compared to normal semen analysis(SMD 1.08, 95\% CI 0.74-1.43). Three other studies not included in the meta-analysis showed a significant negative correlation between mitochondrial DNA copy numbers and semen parameters. The quality of evidence was assessed as good to very good in $60 \%$ of studies. Conclusions: Our review demonstrates significantly higher mitochondrial DNA in human sperm cells of men with abnormal semen analysis in comparison to men with normal semen analysis. PROSPERO registration: CRD42019118841 Funding None received
\end{abstract}

\section{Hosted file}

Manuscript V 1.5.pdf available at https://authorea.com/users/407144/articles/517548-spermmitochondrial-dna-copy-numbers-in-normal-and-abnormal-semen-analysis-a-systematicreview-and-meta-analysis

\section{Hosted file}

Figure 1.pdf available at https://authorea.com/users/407144/articles/517548-spermmitochondrial-dna-copy-numbers-in-normal-and-abnormal-semen-analysis-a-systematicreview-and-meta-analysis

\section{Hosted file}

Figure 2.pdf available at https://authorea.com/users/407144/articles/517548-spermmitochondrial-dna-copy-numbers-in-normal-and-abnormal-semen-analysis-a-systematic-

review-and-meta-analysis 